\title{
IbM PEMBUATAN BERAS KENCUR INSTAN SEBAGAI UPAYA PENINGKATAN KEMANDIRIAN EKONOMI KELUARGA DI KELURAHAN KAHURIPAN KECAMATAN TAWANG KOTA TASIKMALAYA
}

\author{
Lingga Ikaditya ${ }^{1}$, Asep Kuswandi ${ }^{2}$, Adi Wibowo ${ }^{3}$ \\ 1,2,3 Jurusan Farmasi, Politeknik Kesehatan Kemenkes Tasikmalaya, lingga.ikaditya@gmail.com
}

\begin{abstract}
ABSTRAK
Abstrak: Obat tradisional yang sering disebut dengan jamu umumnya khasiat manfaatnya berdasarkan terapi empiris yang merupakan warisan nenek moyang. Pemanfaatan obat tradisional sebagai upaya peningkatan kesehatan masih rendah dan lebih banyak dikonsumsi oleh orang tua dan kondisi ekonomi menengah ke bawah. Aspek yang menyebabkan kurangnya konsumsi jamu adalah proses pengolahan membutuhkan proses lama. Salah satu tanaman yang sudah dimanfaatkan sebagai tanaman obat adalah kencur. Pengolahan kencur secara tradisional sebagai terapi herbal yaitu beras kencur. Oleh karena itu, kegiatan ini bertujuan untuk meningkatkan status kesehatan warga dan meningkatkan kemandirian warga secara ekonomi dengan pengolahan beras kencur instan yang memiliki nilai jual tinggi sehingga pemanfaatannya dapat menjangkau seluruh lapisan masyarakat dengan menawarkan produk sehat, aman dan praktis. Metode yang digunakan yaitu melalui transfer ilmu melaui penyuluhan serta demonstrasi. Khalayak sasaran dari Program Pengabdian Masyarakat berbasis Ipteks bagi Masyarakat (IbM) ini adalah Masyarakat Kelurahan Kahuripan, yang merupakan masyarakat tidak produktif secara ekonomis. Hasil yang diperoleh dari kegiatan pengabdian masyarakat adalah peningkatan pengetahuan kader dalam pemanfaatan produk herbal dan pengolahannya sehingga dapat dihasilkan produk beras kencur instan yang memiliki nilai jual,
\end{abstract}

Kata Kunci: IbM, Kelurahan Kahuripan, Beras Kencur Instan

Abstract: Traditional medicine is often called Jamu has efficacy based on empirical therapy from the ancestral heritage. The use of traditional medicine to maintain or improve health condition are still low and just consumed by the elderly and low economic. The lack of consumption of Jamu caused by its production that requires a long process. One of the plants that have been used as medicinal plants is Kencur (Kaemferia galanga L.). Kencur traditionally used as a herbal therapies such as Beras Kencur. Therefore, this study aims to improve the health status of citizens and increase the citizens economically with the application of science and technology in the field of pharmacy through knowledge transfer to produce Beras Kencur instant into refined products that more valuable so that utilization can reach the whole community by offering healthy products, safe and simple. The method used is to provide guidance to the group through the transfer of knowledge through counseling and demonstration. The target of science and technology based Community Service Program for the Community (IbM) is Kahuripan Urban Village Society, which is not economically productive society. Results obtained from this activity is the increase of knowledge and skill of the group in the use of Jamu and how to process it, so they can produce Beras Kencur instant that more valuable.

Keywords: IbM, Kelurahan Kahuripan, Beras Kencur Instan

Riwayat Artikel: Diterima: 13-12-2017, Disetujui: 30-01-2018 


\section{A. PENDAHULUAN}

Pembangunan adalah suatu proses perubahan yang dilakukan secara berkelanjutan oleh suatu bangsa untuk meningkatkan taraf hidup dan kesejahteraan masyarakatnya. Kemajuan di berbagai bidang akibat kemajuan ilmu pengetahuan dan teknologi merupakan tantangan besar bagi masyarakat untuk senantiasa mampu memanfaatkan dan mengelola lingkungannya. Oleh karena itu diperlukan adanya berbagai program yang dapat dilakukan dalam rangka peningkatan kesejahteraan keluarga dengan memanfaatkan dan mengelola lingkungan sekitarnya [1]

Salah satu program yang dapat dilaksanakan oleh masyarakat dalam upaya peningkatan kesejahteraan keluarga, khususnya di bidang kesehatan adalah program penanaman dan pemanfaatan Tanaman Obat Keluarga (TOGA) [2].) Tingkat konsumsi jamu paling besar adalah usia lebih dari 35 tahun dan semakin tinggi tingkat pendidikan semakin menurun tingkat konsumsi jamu [3]. Oleh karena itu, pemanfaatan obat tradisional sebagai upaya peningkatan kesehatan masih rendah dan lebih banyak dikonsumsi oleh orang tua dan kondisi ekonomi menengah ke bawah. Aspek yang menyebabkan kurangnya konsumsi jamu adalah proses pengolahan membutuhkan proses lama.

Salah satu tanaman yang dapat dimanfaatkan yang memiliki nilai ekonomi yang cukup tinggi adalah produksi jamu beras kencur [1]. Tanaman kencur yang mempunyai nama ilmiah Kaempferia galanga, termasuk golongan klasifikasi Plantae yang merupakan tumbuhan yang memiliki bunga dan buah. Tumbuhan obat yang masih keluarga dengan Temulawak, Bangle, dan Jahe ini sangat mempunyai banyak khasiat untuk pengobatan tradisional. Selain sebagai rempah pendamping buat masakan, kencur juga dijadikan bahan alternatif jamu yang biasanya dikenal dengan sebutan beras kencur yang memiliki antioksidan [4].

Bagi masyarakat Indonesia, racikan jamu tradisional merupakan salah satu warisan budaya yang tak ternilai harganya. Jika awalnya jamu tradisional hanya dijadikan sebagai ramuan obat, sekarang ini minuman tersebut telah diangkat kembali sebagai peluang bisnis baru yang menjanjikan omset besar bagi para pelakunya. Usaha minuman jamu tradisional belakangan ini memang semakin diminati pasar. Salah satu jenis jamu yang sering ditawarkan kepada konsumen adalah beras kencur.

Meskipun terbilang tradisional, namun minuman ini masih punya pasar yang sangat luas. Bahkan saat ini pemasaran jamu tradisional berhasil masuk ke supermarket dan mall besar, tentunya setelah diinovasikan dengan bentuk dan kemasan yang modern. Selain peluang pasar yang masih besar, memulai bisnis jamu tidak membutuhkan modal yang terlalu besar. Dalam kegiatan pengabdian kepada masyarakat berbasis Masyarakat ini, kami berharap masyarakat dapat membuat 
modifikasi beras kencur dengan penerapan IPTEK di bidang kefarmasian sehingga dapat dihasilkan beras kencur instan yang dapat meningkatkan nilai jual beras kencur. Pemanfaatan teknologi formulasi bahan alam tersebut didukung dengan sistem pemasaran produk yang baik sehingga dapat meningkatkan taraf perekonomian masyarakat setempat.

Wilayah yang menjadi tempat kegiatan ini adalah di Kelurahan Kahuripan Kota Tasikmalaya. Kami memilih lokasi ini adalah karena Poltekkes Kemenkes Tasikmalaya berada di Kelurahan Kahuripan, sehingga kami ingin memberikan manfaat sebesar-besarnya untuk masyarakat disekitar kampus kami. Kelurahan Kahuripan kami pilih sebagai tempat kegiatan ini karena merupakan salah satu kelurahan yang banyak mendapatkan bantuan PKH (Program Keluarga Harapan). PKH merupakan suatu program penanggulangan kemiskinan dan meningkatkan kualitas sumber daya manusia terutama pada kelompok masyarakat miskin. Banyaknya jumlah penerima PKH ini menjadi salah satu indikator belum adanya kemandirian ekonomi keluarga yang dapat menanggulangi kemiskinan dan peningkatan kualitas sumber daya manusia. Sehingga dengan adanya kegiatan Ipteks Berbasis Masyarakat ini dapat menurunkan angka penerima PKH secara khusus dan dapat meningkatkan taraf ekonomi masyarakat Kelurahan Kahuripan pada umumnya. Tujuan dari program pengabdian kepada masyarakat adalah diharapkan dapat melakukan pengolahan beras kencur menjadi bentuk instan sehingga lebih praktis untuk digunakan.

\section{B. METODE PELAKSANAAN}

Metode pelaksanaan pada program ini yaitu dengan metode transfer ilmu melalui penyuluhan, pelatihan dan demonstrasi dari tim Dosen Jurusan Farmasi Poltekkes Kemenkes Tasikmalaya dibantu mahasiswa kepada warga di Kelurahan Kahuripan Kota Tasikmalaya khususnya terkait pengolahan tanaman kencur. Dalam rangka mencapai tujuan maka ditempuh langkah-langkah sebagai berikut:

1. Menghubungi Camat Tawang dan Lurah Kelurahan Kahuripan untuk perizinan kegiatan pengabdian masyarakat di wilayah kerja Kelurahan Kahuripan.

2. Mencari data jumlah masyarakat yang produktif sebagai calon peserta pelatihan.

3. Menghubungi Dinas Kesehatan Kota Tasikmalaya untuk mendiskusikan tata cara perizinan minuman kesehatan.

4. Menyelenggarakan penyuluhan dan pelatihan dengan materi:
a. Manfaat Tanaman Obat Kencur
b. Macam-macam produk kesehatan dari olahan kencur
c. Persiapan produksi dan praformulasi produk Kencur 
d. Pendampingan strategi pemasaran produk

e. Pendampingan pembuatan PIRT

Evaluasi kegitan dilakukan dengan menilai keberhasilan kegiatan ini dengan melihat indikator yaitu $80 \%$ peserta hadir dalam pelatihan, $50 \%$ peserta mampu memproduksi produk kesehatan dari Tanaman Obat Kencur dan peningkatan nilai postes dari sebelum dilakukan kegiatan (pretes).

\section{HASIL DAN PEMBAHASAN}

\section{Tahapan Pelaksanaan Kegiatan}

Adapun Kegiatan yang dilakukan dalam menyelesaikan permasalahan di Kelurahan Kahuripan Kota Tasikmalaya adalah sebagai berikut :

a. Pembuatan kelompok kader

Pembutan kelompok bertujuan untuk meningkatkan kerjasama untuk mencapai tujuan kegiatan. Dengan berkelompok diharapkan akan tercipta semangat bersama sehingga dalam pelaksanaan pengabdian masyarakat ini dapat berjalan dengan lancar dengan dukungan kontribusi kelompok. Pemilihan kelompok berdasarkan kriteria orang yang aktif dan mampu bekerjasama dalam tim. Pemilihan kader diserahkan kepada ketua kader Kelurahan Kahuripan untuk memilih sesuai kriteria yang ditentukan. Berdasarkan pemilihan didapatkan 6 orang kader aktif yang akan dilibatkan dalam kegiatan pengabdian masyarakat ini khususnya dalam pembuatan beras kencur instan.

b. Pretes

Pretes dilakukan untuk melihat pemahaman awal kader sebelum dilakukan kegiatan. Berdasarkan hasil pretes didapatkan hasil yaitu rata-rata tingkat pengetahuan warga terkait materi penyuluhan adalah pada kategori cukup yaitu 47.5\%. Kategori tersebut sesuai dengan Notoatmodjo [4] dimana tingkat pengetahuan sangat baik 76$100 \%$, pengetahuan baik 51-75\%, pengetahuan cukup baik $26-50 \%$ dan pengetahuan tidak baik 0-25\%.

c. Penyuluhan

Jadwal penyuluhan disesuaikan dengan jadwal kader dan narasumber sehingga kehadiran kader 100\%. Penyuluhan yang dilakukan berupa :

1) Penyuluhan dilakukan dalam rangka transfer knowledge kepada kader tentang proses pembuatan produk mencakup teknik pemilihan bahan baku, teknik sortasi basah dan kering, pembuatan simplisia dan penyimpanan. Hal tersebut guna 
memberikan pengetahuan awal sebelum dilakukan praktek pembuatan sediaan/produk.

2) Penyuluhan Pemasaran produk. Penyuluhan ini bertujuan untuk menumbuhkan jiwa kewirausahaan kader dan memberikan pengetahuan tentang strategi pemasaran produk terkait dengan marketing mix (product, price, place, dan promotion). Dengan pengetahuan tersebut diharapkan sebagai bekal kader untuk membangun usaha.

3) Penyuluhan tentang PIRT dilakukan oleh Dinas Kesehatan Kota Tasikmalaya. Dalam Penyuluhan tersebut dipaparkan tata cara mendapatkan izin PIRT. Untuk mendapatkan izin PIRT, setiap kelompok/perorangan perlu dilakukan pelatihan keamanan pangan oleh tim penyuluh Dinas kesehatan. Kegiatan pelatihan tersebut belum dapat dilakukan tahun ini mengingat ahir tahun kegiatan tidak ada agenda pelatihan. Sehingga kegiatan pelatihan akan diagendakan tahun depan.

d. Pendampingan Produksi

Produksi dilakukan di rumah kader. Setiap kader diberikan alatalat yang dibutuhkan untuk produksi. Pendampingan produksi dilakukan oleh tim pengabmas, instruktur dari Jurusan Farmasi, serta mahasiswa. Proses produksi membutuhkan waktu sekitar 6 jam. Dalam proses produksi didukung oleh antusias kader dalam mengikuti pelatihan pembuatan produk.

Hasil produksi berupa serbuk kering instan yang akan dikemas menjadi minuman siap saji. Kemasan yang digunakan untuk pengemasan dibuat dari bahan papercup sehingga diharapkan dengan kemasan yang lebih eye catching dapat memperluas segmentasi produk jamu tidak hanya kalangan orang tua tapi bisa masuk ke segmentasi remaja. Serta produk yang ditawarkan berupa jamu yang relatif lebih tahan lama dengan dibuat dalam bentuk serbuk instan.

e. Postes

Postes dilakukan untuk evaluasi keberhasilan program terkait pemahaman kader terhadap transfer knowledge yang dilakukan terhadap Pengetahuan tentang pemanfaatan beras kencur, Keterampilan tentang pengolahan beras kencur instan, Pengetahuan dalam melakukan pemasaran produk dan Pengetahuan dalam perizinan minuman kesehatan.

Berdasarkan hasil postes didapatkan nilai rata-rata tingkat pengetahuan yaitu $72,5 \%$. Nilai tersebut menunjukkan bahwa berdasarkan kategori tingkat pengetahuan menurut Notoatmodjo [4] bahwa kategori tingkat pengetahuan kader pada kategori baik dalam menerima transfer knowledge yang dilakukan oleh narasumber. Dari hasil tersebut dapat dilihat pada tabel 1. bahwa terjadi pergeseran 
tingkat pengetahuan sebelum dilakukan penyuluhan dan setelah dilakukan penyuluhan dari kategori tingkat pengetahuan cukup ke tingkat pengetahuan baik.

TABEL 1

INDIKATOR TINGKAT PENGETAHUAN KADER

\begin{tabular}{|c|c|c|}
\hline Indikator & Sebelum Penyuluhan & Setelah Penyuluhan \\
\hline $\begin{array}{c}\text { Rata-rata tingkat } \\
\text { Pengetahuan }\end{array}$ & 47,5 & 72,5 \\
\hline $\begin{array}{c}\text { Kategori Tingkat } \\
\text { Pengetahuan }\end{array}$ & Cukup & Baik \\
\hline
\end{tabular}

\section{f. Monev}

Monev dilakukan untuk melihat keberhasilan produk yang dibuat. Berdasarkan hasil monev sediaan produk serbuk instan sudah dikemas dalam plastik. Pengemasan bahan tersebut berguna agar sediaan dapat awet dalam penyimpanan.

\section{Faktor Pendukung dan Kendala}

Faktor pendukung dalam kegiatan ini adalah peran aktif dari kader sehingga kegiatan dapat berjalan sebagaimana yang telah direncanakan. Adapun kendala dalam kegiatan ini adalah penyesuaian jadwal kegiatan sekaitan dengan kesibukan masing-masing.

\section{Program Tindak Lanjut}

Berdasarkan evaluasi penyimpanan diperlukan pengemasan menggunakan bahan alumunium foil untuk menjaga stabilitas sediaan agar lebih tahan lama. Mengingat bahan baku sediaan tanpa pengawet dan adanya bahan gula yang cepat membuat serbuk menjadi lembab. Hasil lain yang ditemukan bahwa berdasarkan pengujian rasa perlunya adanya formulasi bahan untuk menghilangkan rasa getir dari kencur yang masih sedikit terasa yang merupakan rasa khas dari kencur. Tindaklanjut yang akan dilakukan adalah memodifikasi formula dan penggunaan teknologi pembuatan agar menghilangkan rasa getir tanpa menghilangkan rasa khas aslinya.

\section{SIMPULAN DAN SARAN}

Adanya pengabdian kepada masyarakat program IbM tahun anggaran 2017 untuk kader kelurahan Kahuripan Kota Tasikmalaya dalam hal transfer teknologi pembuatan beras kencur instan menghasilkan :

1. Peningkatan pengetahuan kader dalam pemanfaatan produk herbal dan pengolahannya sehingga dapat dihasilkan produk yang memiliki nilai jual. 
2. Keterampilan kader dalam Pembuatan beras kencur instan sehingga menghasilkan produk siap saji yang memiliki nilai jual.

3. Peningkatan pengetahuan kader dalam teknik pemasaran.

4. Peningkatan pengetahuan kader dalam tata cara perizinan minuman kesehatan yang dapat meningkatkan jaminan kualitas produk

Program tindak lanjut dari program ini adalah Perlu dilakukan pengabdian masyarakat lanjutan dalam hal pendampingan kewirausahaan dan pemasaran produk sehingga produk yang dihasilkan dapat dijual dan meningkatkan kemandirian masyarakat secara ekonomi.

\section{UCAPAN TERIMA KASIH}

Tim penulis mengucapkan terima kasih kepada Lurah Kahuripan, kepala Puskesmas Kahuripan dan Camat Tawang atas bantuan koordinasinya, juga Unit Penelitian dan Pengabdian kepada Masyarakat (UPPM) Politeknik Kesehatan Kemenkes Tasikmalaya yang telah mendanai program ini melalui DIPA Poltekkes, sehingga program ini terlaksana dengan baik.

\section{DAFTAR RUJUKAN}

[1] Hastuti, , dan khatimah, Pemberdayaan Ibu Rumah Tangga Di Desa Purwobinganun Kecamatan Pakem Kabupaten Sleman Dalam Penanaman Dan Pemanfaatan Tanaman Obat Keluarga, Laporan Pengabdian Masyarakat, Universitas Negeri Yogyakar, 2014.

[2] Liya, B. K. dan Farid, M.M, Proses Pemberdayaan Melalui Paguyuban Tanaman Obat Keluarga (Toga) Di Kelurahan Tlogoanyar Kabupaten Lamongan, Publika, Vol.3(7), 2015.

[3] Riset Kesehatan Dasar (Riskesdas), Balai Penelitian dan Pengembangan Kesehatan, Laporan Penelitian, Kementerian Kesehatan RI, Jakarta, 2014.

[4] Widowati, W, Potensi Antioksidan sebagai Antidiabetes, Journal KM, 7(2:)1-11, Feb 2008.

[5] Notoatmodjo, Soekidjo, Pendidikan Dan Perilaku Kesehatan, Rineka Cipta, Jakarta, 2003 


\section{DOKUMENTASI KEGIATAN}

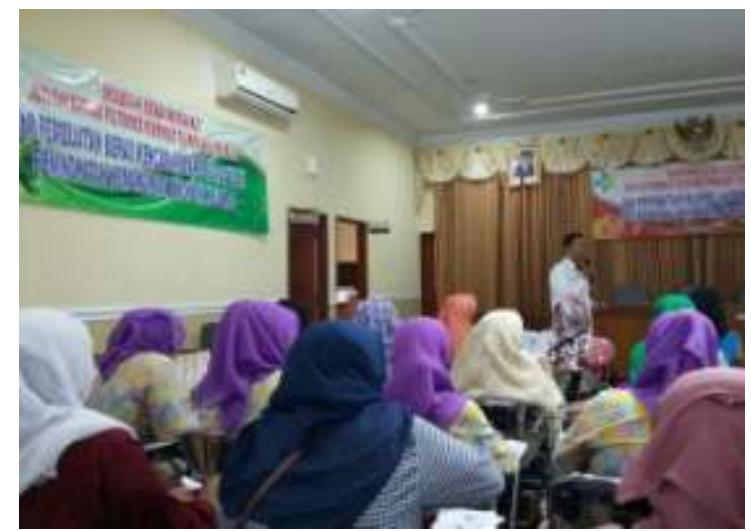

Gambar 1. Penyuluhan Pembuatan Produk

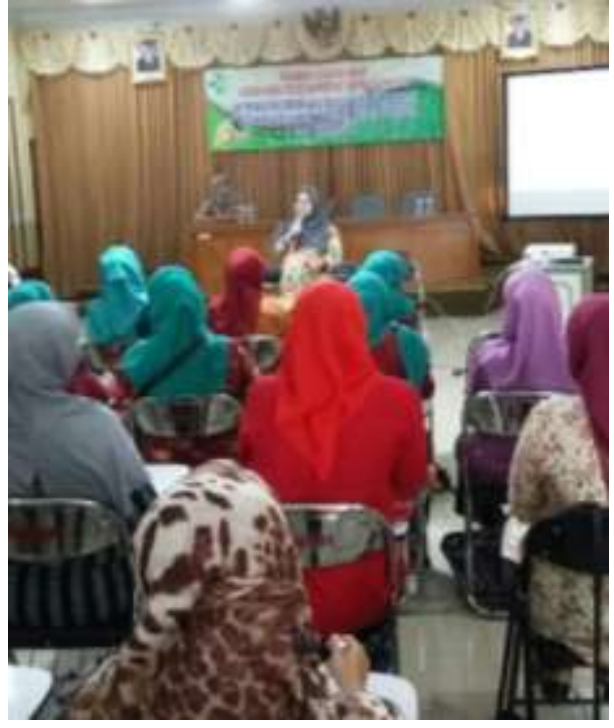

Gambar 3. Penyuluhan Tata Cara Perizinan Minuman Kesehatan

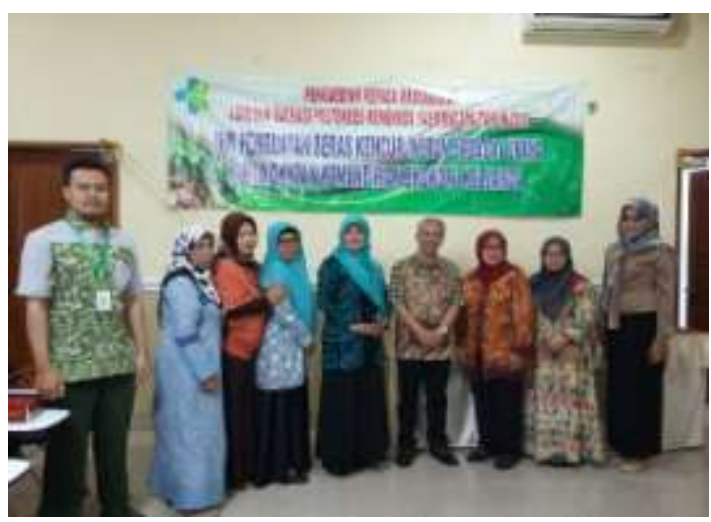

Gambar 2. Foto bersama dengan peserta dan Tim Kelurahan Kahuripan

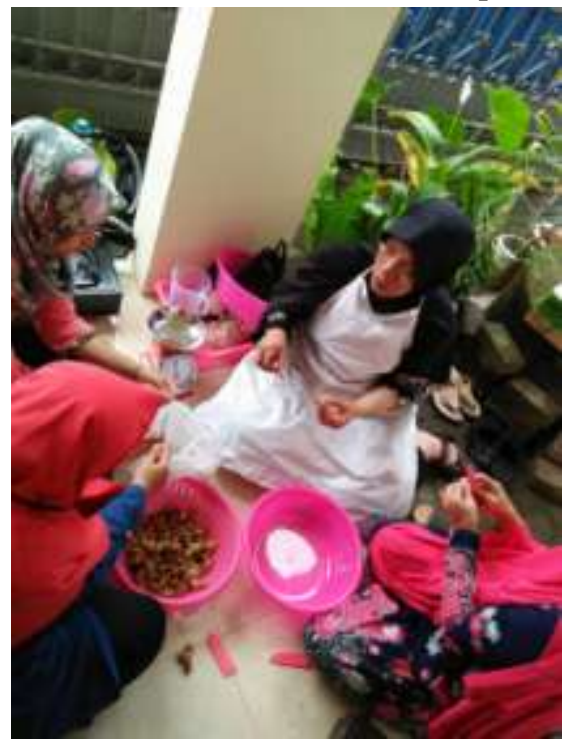

Gambar 4. Pendampingan Produksi Beras Kencur Instan 